\title{
Phytorestoration of Sewage Sludge from the Mangrove Landfill of «Bois des Singes» by Planted Filters of Pennisetum purpureum (Douala, Cameroon)
}

\author{
Promesse-ssie Mpahmadje Yves ${ }^{1}$, Ndjouondo Gildas Parfait ${ }^{2}$, Noukeu Nkouakam Armelle ${ }^{3}$, \\ Dibong Siegfried Didier ${ }^{1}$, Ndongo Din ${ }^{1}$, Priso Richard Jules ${ }^{1, *}$ \\ ${ }^{1}$ Department of Botany, Faculty of Science, The University of Douala, Douala, Cameroon \\ ${ }^{2}$ Department of Biology, Higher Teacher Training College, The University of Bamenda, Cameroon \\ ${ }^{3}$ Department of Botany, Faculty of Science, The University of Yaounde I, Cameroon
}

\author{
Email address: \\ r_priso@yahoo.fr(P. R. Jules) \\ ${ }^{*}$ Corresponding author
}

\section{To cite this article:}

Promesse-Ssie Mpahmadje Yves, Ndjouondo Gildas Parfait, Noukeu Nkouakam Armelle, Dibong Siegfried Didier, Ndongo Din, Priso Richard Jules. Phytorestoration of Sewage Sludge from the Mangrove Landfill of «Bois des Singes» by Planted Filters of Pennisetum purpureum (Douala, Cameroon). International Journal of Environmental Protection and Policy. Vol. 9, No. 2, 2021, pp. 33-39. doi: 10.11648/j.ijepp.20210902.13

Received: January 31, 2021; Accepted: February 8, 2021; Published: April 13, 2021

\begin{abstract}
Human activities are causing wetland degradation. Macrophytes play an important role in the management of hydrosystems. They can therefore be used to restore a polluted environment. The aim of the study is to contribute to the phytorestoration of sewage sludge in nitrates, phosphates, cadmium, iron and lead from the Mangrove landfill of "Bois des singes" by planted filters of Pennisetum purpureum. A planted filter of $P$. purpureum was constructed. Sewages sludges samples were introduced into the device. Nitrates $\left(\mathrm{NO}_{3}\right)$, phosphates $\left(\mathrm{PO}_{4}\right)$, cadmium $(\mathrm{Cd})$, iron $(\mathrm{Fe})$ and lead $(\mathrm{Pb})$ assays were carried out in water and plants at different levels of the filter (Settling basin B1, basin B2, basin B3, negative control and positive control) by absorption spectrophotometry flame atomic. The bioaccumulation and translocation factors as well as the bioaccumulation coefficient have been determined. The high contents of $\mathrm{PO}_{4}(4000 \mathrm{mg} / \mathrm{l}), \mathrm{NO}_{3}(89 \mathrm{mg} / \mathrm{l}), \mathrm{Fe}(5000 \mathrm{mg} / \mathrm{l}), \mathrm{Pb}$ $(20 \mathrm{mg} / \mathrm{l})$ and $\mathrm{Cd}(0.08 \mathrm{mg} / \mathrm{l})$ are greatly reduced by the filters at values below the tolerance threshold in $\mathrm{B} 3 \mathrm{of} 0.01 \mathrm{mg} / \mathrm{l}, 0.14$ $\mathrm{mg} / 1,0.0002 \mathrm{mg} / \mathrm{l}, 0.0003 \mathrm{mg} / \mathrm{l}$ and $0.0003 \mathrm{mg} / \mathrm{l}$ respectively. The bioaccumulation factor shows that $P$. purpureum contained in barrels where the parameters are high is lead accumulator with a value of 1.305 (B2), hyperaccumulator of $\mathrm{Fe}$ and $\mathrm{Cd}$ with values of 10.05 (B2) and 13, 23 (B3). The leaf translocation is greater than 1 with $\mathrm{Fe}$ and $\mathrm{Pb}$ in the leaves of the boles. $P$. purpureum transfers $\mathrm{Fe}$ and $\mathrm{Pb}$ to the leaves. The planted filter of $P$. purpureum allows a restoration of this sewage sludge. This macrophyte extracts $\mathrm{NO}_{3}, \mathrm{PO}_{4}, \mathrm{Cd}, \mathrm{Fe}$ and $\mathrm{Pb}$ and accumulates them in its vegetative system. $P$. purpureum cant be use to to restore the environment stressed by faecal sludge in the city of Douala.
\end{abstract}

Keywords: Macrophytes, Phytorestoration, Faecal Sludge

\section{Introduction}

Water earth's surface is distributed in variors reservoirs, $97.5 \%$ of which is in the form of salt water and $2.5 \%$ in the form of fresh water. In fact, $2 / 3$ of the planet's fresh water reserve is retained in the ice of the polar regions. Humanity must meet all its water needs with only $1 / 3$ [1]. In order to combat the scarcity of fresh water available for human activities, several collective wastewater treatment systems have already been tested or curently being tested in Africa. A census carried out in 1993 showed that purification techniques using activated sludge represented $75 \%$ of the 155 treatment plants identified and, that almost all of them were either stopped or in poor working order [2].

The implementation of activated sludge systems has been a failure because they offered very little flexibility in operation and cannot be easily adapted to the context of African 
countries [3]. In addition to the fact that they do not provide very good bacterial purification (which would be a considerable advantage in these countries), these stations also do not support large variations in flow rates. They have also proved to be too costly in terms of investment, operating and management costs, and they are dependent on spare parts which are sometimes unavailable on the local market. Until, the solution to this challenge is found, the volume of urban wastewater is only increasing with the expansion of cities [2].

In light of these various observations, several researchers propose purification by extensive type processes, which are natural water purification systems, the best known of which is lagooning by planted filters of macrophytes [2].

Anthropogenic activities in Douala have harmful effects on water quality through the production of domestic and industrial waste, the discharges of which are very often made in natural hydrosystems without prior treatment. This situation is due to the worsened multiplicity of anarchic urban installations and the insufficiency of appropriate structures for the treatment of wastewater [4]. This wastewater is generally a mixture of pollutants meeting these categories, dispersed or dissolved in the water used for domestic or industrial needs [5]. Given the poor performance of conventional structures and their unsuitability for the Cameroon context, much interest has been focused in recent decades on phyto-purification of wastewater. The technologies developped exploits the adaptation capacities of root systems to high pollutant loads and to the conditions of anoxia or hypoxia of the substrate, leading to symbiotic relationships between microorganisms and the roots which favor the elimination of pollutants [6]. Wastewater, whether industrial or domestic, should not be directly discharged into the natural environment. The purpose of treating or purifying wastewater is therefore to reduce the pollutant load that it carries. Consequently, they should be sent to wastewater treatment plants, which role is to concentrate the pollution contained in wastewater in the form of a small volume of residue (sludge) to discharge purified water that meets very precise standards, thanks to physico-chemical and biological processes [6]. The absence and insufficiency of water restoration devices or the none ecological water treatment remain major problems in several cities in southern Africa.

The «Bois des singes » landfill is a pit built in the form of a filter with two settling tanks. However, liquid and solid pollutants are directly discharged into the natural environment due to the poor condition of the basins. These pollutants come from septic tanks, the food and chemical industries, and household activities. The municipal dump of "Bois des singes" still in use is not maintained by the State, and is almost in ruins. A mini-channel serving as a drain has been built by the local population who is settling more and more on the landfill. However, before the spontaneous and uncontrolled settlement of populations in this Mangrove, the purification of the sludge was natural. Currently where the vegetation and the aquatic environment have completely disappeared, waste is discharged directly into the immediate environment and into Wouri river, with numerous consequences such as diseases linked to heavy pollution, loss of biodiversity and floods. After observing the vegetation of the area, it emerges that Pennisetum purpureum is the most common plant in the environment. Anything that shows that this plant has adaptive capacities that allow it to withstand the sewage sludge of the city of Douala. Can Pennisetum purpureum purify the environment stressed by faecal sludge?

The aim of the study is to contribute to the phytorestoration of faecal sludge in nitrates, phosphates, cadmium, iron and lead from the Mangrove landfill of 'Bois des singes" by planted filters of $P$. purpureum for the preservation of the littoral zone.

\section{Materials and Methods}

\subsection{Materials}

The "Bois des singes" Mangrove (0350'-04 $10^{\circ}$ ' $\mathrm{N}$ and $09^{\circ} 20^{\prime}-09^{\circ} 50^{\prime}$ E) is located in the Gulf of Guinea. It is located on the south bank of the Wouri estuary, Cameroon Littoral region, Wouri Department, Douala $2^{\text {nd }}$ arrondissement [7].

The study took place from February 1 to July 1, 2019. At the landfill, effluents were collected in a 2001 drum. Stems of $P$. purpureum were harvested by cutting the plant with a collar using a knife. These rods were cleaned and rinsed with distilled water.

Three (3) tables were built with three shelves each. Three (3) half-barrels of 1001 were placed in series on each table, connected to each other by a PVC pipe fitted with a quarterturn valve, so that the first half-barrel discharges is contained in the second, and the second in the third. Pozzolan, coarse sand and fine sand after washing and rinsing with distilled water, were respectively deposited from the bottom to the top in each half-barrel according to a thickness of $15 \mathrm{~cm}$ for each layer.

\subsection{Methods}

\subsubsection{Field Methods}

P. purpureum was transplanted into the ponds in tables 2 and 3 only. Table 1 is considered as the negative control (T1) without plants with the sewage sludge, table 2 is considered as the positive control (T2) with plants without sewage sludge and table 3 (experimental) contains the plants and effluent. On experimental table 3, the basins arranged in series have been numbered from top to bottom respectively as follows: B1, B2 and B3. B1 corresponds to the first basin (settling basin), B2 to the second basin (first treatment basin) and B3 to the third basin (second treatment basin). Cuttings of $P$. purpureum were cut $6 \mathrm{~cm}$ from each side of each node. They were transplanted at a density of 5 plants per barrel (positive control, B2 and B3).

After assembly of the device, drilling water was poured into the positive control drums, B2 and B3 until a column of $3 \mathrm{~cm}$ was obtained above the layer of fine sand. Two weeks later, when the cuttings gave young seedlings, the sewage sludge decanted for $24 \mathrm{~h}$ in the settling barrel (B1) was transferred to 
the negative control and B2 barrels for a stay of 2 weeks. After this step, the water from B2 was directly transferred (by opening the tap) to B3 for another 2-week stay.

Samples of raw water (effluent), water leaving the control and experimental basins were taken in 11 jars stored in a cooler at $-4^{\circ} \mathrm{C}$ for assay of the color (C). The biological oxygen demand $\left(\mathrm{BOD}_{5}\right)$, suspended organic matter (MOS), suspended mineral matter (MMS), turbidity (turb), conductivity (cond), $\mathrm{pH}$, nitrates $\left(\mathrm{NO}_{3}\right)$, phosphates $\left(\mathrm{PO}_{4}\right)$, cadmium $(\mathrm{Cd})$, iron $(\mathrm{Fe})$ and lead $(\mathrm{Pb})$ at the hydrobiology laboratory of the University of Yaounde 1. The plants were collected in each basin. The roots, stems and leaves of each plant sample were separated, cut into small portions, washed and rinsed with distilled water. The samples were dried at $110^{\circ} \mathrm{C}$ in an oven for $24 \mathrm{~h}$. The dried samples were taken to the Soil, Plants, Fertilizers and Water Analysis Laboratory (SPFWAL) in Nkolbisson (Yaoundé) for determination of the cadmium, iron and lead contents. All these laboratory samples were assayed by flame atomic absorption spectrophotometry according to the method of [8].
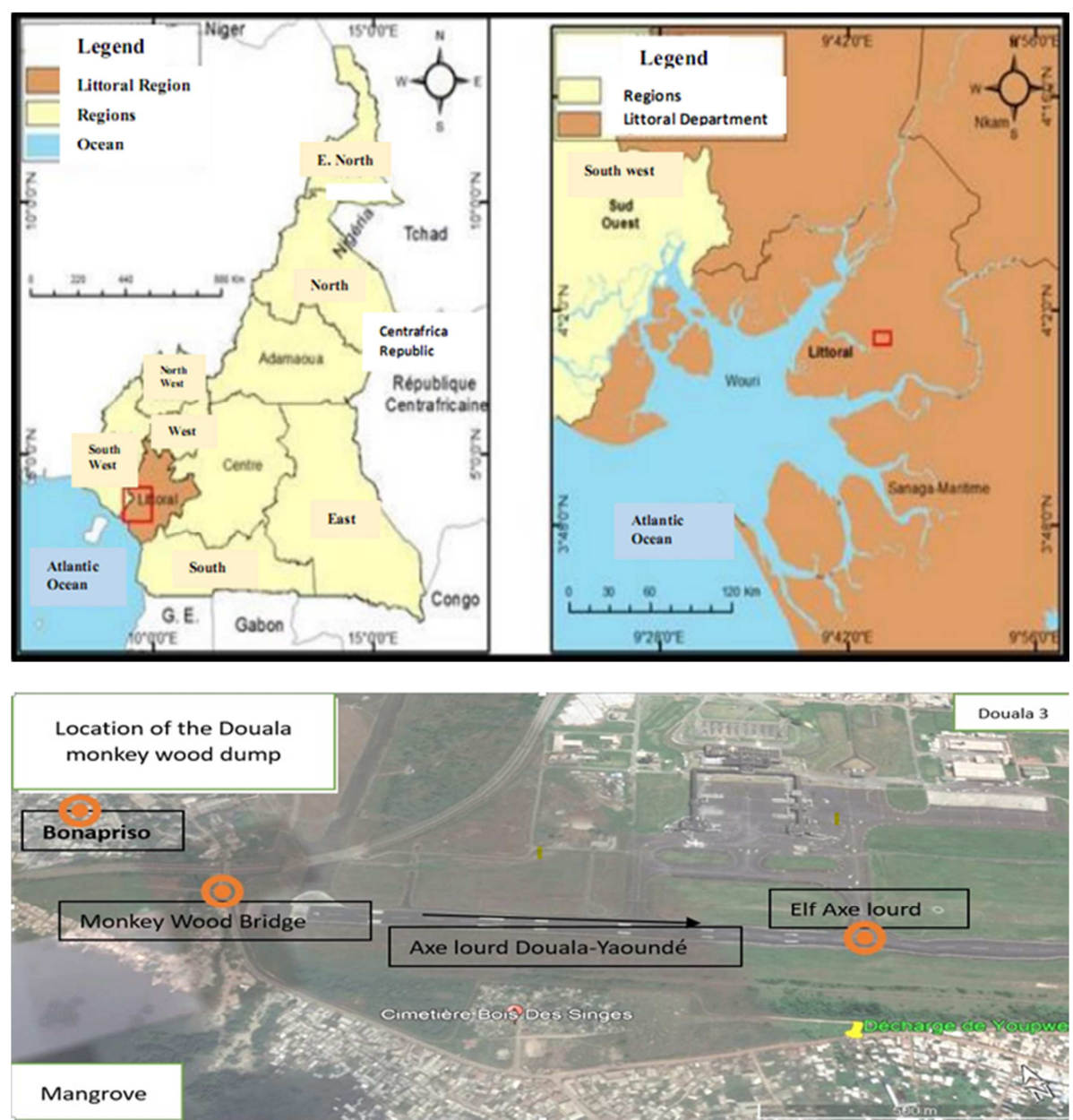

Figure 1. Location of study area.

\subsubsection{Analytical Methods}

The Bioaccumulation Factor (BAF): it is used to quantify the toxic metals effectively accumulated in plants by comparing the concentration in the plant and the external environment. $\mathrm{BAF}=\mathrm{Cb} / \mathrm{Cs}, \mathrm{Cb}$ and $\mathrm{Cs}$ are the heavy metal concentrations in the various parts of the plant considered $(\mathrm{mg} / \mathrm{kg})$ and water $(\mathrm{mg} / \mathrm{l})$ respectively. The BAF was considered as [9]: <1 non-accumulator, 1-10 accumulator and $>10$ hyper-accumulator. The Bioaccumulation Coefficient (BAC): it was determined to qualify the toxic metals effectively accumulated in plants by comparing the concentration in the different organs of the plant (roots, stems and leaves) and the external environment such as the watercourse used in the following formula: $\mathrm{BAC}=\mathrm{Cp} / \mathrm{Cs}, \mathrm{Cp}$ and Cs are the heavy metal concentrations in the different parts of the plant $(\mathrm{mg} / \mathrm{kg})$ and in water $(\mathrm{mg} / \mathrm{l})$, respectively [10]. Four categories of heavy metal accumulation have been proposed: $<0.01$ non-accumulating plants, 0.01-0.1 slightly accumulating plants, 0.1-1 moderately accumulating plants and 1-10 hyperaccumulating plants. The translocation of heavy metals from roots to leaves in plants was calculated using the following formula: $\mathrm{TF}=\mathrm{Cs} / \mathrm{Cr}, \mathrm{Cs}$ and $\mathrm{Cr}$ are the heavy metal concentrations $(\mathrm{mg} / \mathrm{kg})$ in the leaves and roots, respectively. TF $>1$ means that the plant effectively transfers heavy metals from the roots to the leaves [10].

The multiple comparison of the variables studied was carried out by the parametric ANOVA one-factor test, using software XLSTAT version 11.0.0.28844. The differences were considered significant for $p<0.05$. This software was 
also used to trace the dendrogram and to perform the representation of the similarities between the water exited from the filters by principal component analysis (PCA).

\section{Results and Discussion}

\subsection{Physico-Chemical Parameters of the Different Study Environments}

The PCA results show the organization of 12 variables measured on the F1xF2 plans $(98.78 \%$ inertia), represented in the form of correlation circles (Figure 1). The F1 axis $(83.15 \%$ inertia) is positively correlated with $\mathrm{Pb}, \mathrm{Fe}$, color, $\mathrm{BOD}_{5}, \mathrm{pH}$, MOS, MMS, turb, $\mathrm{PO}_{4}$ and $\mathrm{Cd}$. It is negatively correlated to cond and to $\mathrm{NO}_{3}$. The $\mathrm{F} 2$ axis $(15.63 \%$ inertia) is positively correlated with $\mathrm{NO}_{3}, \mathrm{~Pb}$, color, $\mathrm{BOD}_{5}, \mathrm{pH}$, MOS and MMS and it is negatively correlated with $\mathrm{PO}_{4}$, turb, $\mathrm{Cd}, \mathrm{Fe}$ and water cond. The Biplot shows three groups correlated according to the level of pollution. Group 1 consists of raw water with high levels of $\mathrm{Cd}, \mathrm{Fe}, \mathrm{Pb}, \mathrm{pH}, \mathrm{BOD}_{5}, \mathrm{MES}, \mathrm{PO}_{4}$, color and turb. Group 2 is that of the negative control filter outlet water. It is distinguished from the others by a higher conductivity value. Group 3 is made up of water from B2 and B3, with lower physicochemical parameters than groups 1 and 2 .

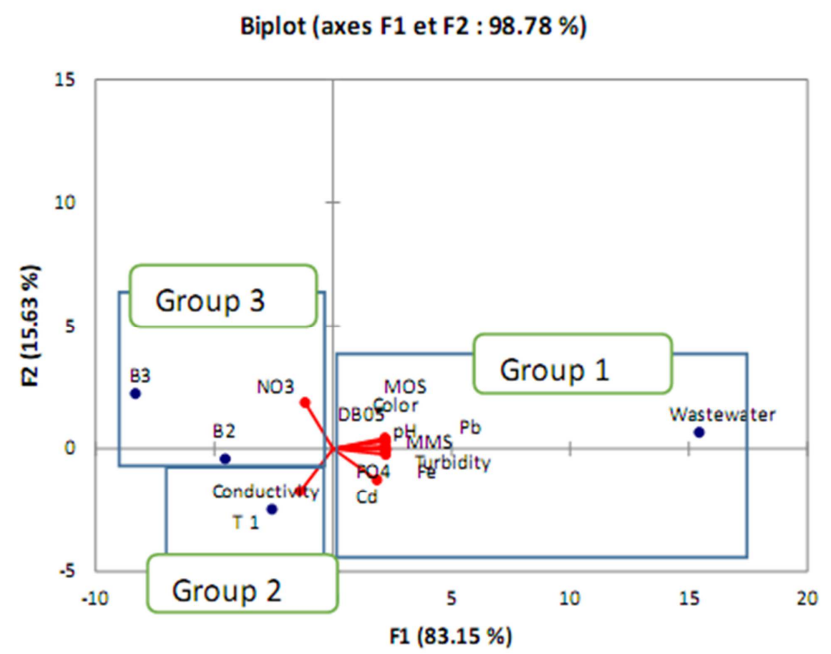

Figure 2. Correlation of the groups as a function of pollution level (a) and dissimilarity between the raw water and the water leaving the negative control drums (witness 1), B2 and B3 (from the experimental table) (b).

The physicochemical parameters decrease significantly from the raw water (sewage sludge) until the outlet of the basin $\mathrm{B} 3$ (Table 1). The basic $\mathrm{pH}$ of raw water from 9.7 is reduced at the outlet of $\mathrm{B} 2$ and $\mathrm{B} 3$ to a neutral $\mathrm{pH}$ of 6.9 with no significant difference between the two basins. The water remaining in $\mathrm{B} 2$ at the end of the experiment is 5.8 acid. Meanwhile, the electrical conductivity follows the same sequence. It decreases from the sewage sludge until the exit of B2. However, it increases between the raw water at the start and that remaining in B2 at the end. In all samples, it is noted that the MES contents decrease. The values of MOS and MMS in raw water are 69.45 and $135 \mathrm{mg} / 1$ respectively. At the outlet of the planted filter, these values increased to
12.7 and $62.78 \mathrm{mg} / \mathrm{l}$ respectively, and in the water outlet of the negative control filter these values are $25.75 \mathrm{mg} / \mathrm{l}$ for the MOS and $82.78 \mathrm{mg} / \mathrm{l}$ for MMS. The color and the turbidity decrease significantly from the polluted water to the water leaving the experimental device. These respective values of color and turbidity are as follows: $363 \mathrm{Pt}-\mathrm{Co}$ and $245 \mathrm{FTU}$ at the outlet of the negative control filter; $137 \mathrm{Pt}-\mathrm{Co}$ and 178 FTU at the exit of $\mathrm{B} 3$. $\mathrm{BOD}_{5}$ decreases from raw water $(450$ $\mathrm{mg} / \mathrm{l})$ to $\mathrm{B} 3$ outlet water $(15 \mathrm{mg} / \mathrm{l})$. High $\mathrm{PO}_{4}(0.01 \mathrm{mg} / \mathrm{l})$, $\mathrm{NO}_{3}(0.14 \mathrm{mg} / \mathrm{l}), \mathrm{Fe}(0.0002 \mathrm{mg} / \mathrm{l}), \mathrm{Pb}(0.0003 \mathrm{mg} / \mathrm{l})$ and $\mathrm{Cd}$ $(0.0003 \mathrm{mg})$ contents are greatly reduced by the filter to values well below the tolerance threshold, prescribed by the Cameroonian environmental standard of $10 \mathrm{mg} / 1,20 \mathrm{mg} / \mathrm{l}$, $0.3 \mathrm{mg} / 1,0.05 \mathrm{mg} / \mathrm{l}$ respectively and $0.001 \mathrm{mg} / \mathrm{l} \mathrm{in} \mathrm{B} 3$.

There is a remarkable reduction in organic pollution parameters $\left(\mathrm{BOD}_{5}, \mathrm{MOS}\right)$. On the treatment of urban wastewater by activated sludge. They concluded that the process after treatment in the filter eliminates more than $2 / 3$ of the total and soluble organic pollution. The color of the water is dark at the inlet of the filter and light at the outlet; this expresses the very high turbidity noticed, in the sewage sludge, which tends to decrease during filtration. These observations indicate the decrease in suspended solids in the water barrel. This color at the outlet of the colorless filter complies with rejection standards (colorless) [11]. These results are in agreement with those of Bachi, 2010 [12] in the Diagnosis on the valuation of some plants in the garden; which confirms the effectiveness of the treatment in eliminating particulate pollution. The $\mathrm{pH}$ values of the sampled water comply with the discharge standard $(6.5<\mathrm{pH}<8.5)$. This decrease in $\mathrm{pH}$ at the filter level is explained by respiration and the photosynthetic activity consuming $\mathrm{H}^{+}$protons by plants $[13,14]$.

Nitrates have been taken up by plants because their levels have dropped in water. This decrease is linked to the fact that plants extract nitrates by root absorption and have used them in metabolism, during the photosynthesis process. These observations are supported by the results of studies by Dekhil and Zaibet 2013 [6], which focused on the performance of planted filters of Echinochloa pyramidalis in the treatment of distillery wastewater. Their results show that plants favor mineralizing microorganisms and improve the purifying capacities of filters.

The phosphates contents decreased considerably at the exit of the water from the planted filter. These results are matching with those of Kone, 2002 [2] on the treatment of wastewater by microphyte and macrophyte lagooning in West and Central Africa. The same observations are made by Eva et al., 2011 [15] during their work on the purification of wastewater by filters planted with reeds. Indeed, during the activity of microorganisms, inorganic phosphorus is mobilized in phosphorus assimilated by plants because the different phosphate ions obtained can be reorganized for the benefit of organisms and then will be assimilated by plants.

The contents of $\mathrm{Cd}, \mathrm{Fe}$ and $\mathrm{Pb}$ in the sewage sludge used are higher than those of the filter outlet. Because this water was subject to a treatment in a macrophyte [16]. In other words, the plants were able to extract some of these heavy 
metals from the soil which they used as support, unlike other plants which do not need support. They almost have the common capacity to absorb and store heavy metals such as $\mathrm{Cd}, \mathrm{Pb}$ and $\mathrm{Fe}$ present in wastewater as illustrated by the Convention on Wetlands [17]. The plant then becomes a pumping and filtration system from which its tissues are the extractors that can find, alter and/or transport elements and compounds against important chemical gradients [19]. During this extraction, they also absorb other compounds dissolved in the aqueous phase. This characteristic is important in the phyto-depollution process because plants are capable of absorbing large quantities of water which they draw at depths of 2 to 5 meters or more for certain plants such as alfalfa or phreatophyte plants [20]. Living organisms are constantly subject to environmental constraints. In the case of plants, their immobility constitutes an important factor of pressure in their adaptation during evolution [21].

Table 1. Physico-chemical parameters of the water in the different barrels. Cond=conductivity, $\mathrm{PO}_{4}=$ phosphates, Turb.=turbidity, $\mathrm{Fe}=$ iron, $\mathrm{Pb}=$ lead, $\mathrm{NO}_{3}=$ nitrates, $\mathrm{BD}=$ raw water, $\mathrm{ST} 1=$ negative control, $\mathrm{SB} 2=$ water leaving barrel B2, SB3=water leaving barrel B3, N=standard; the boxes of the columns with the same letter have no significant difference, $p<0.05$.

\begin{tabular}{|c|c|c|c|c|c|}
\hline \multirow{2}{*}{ Parameters } & \multicolumn{5}{|l|}{ Water } \\
\hline & BD & ST1 & SB2 & SB3 & $\mathbf{N}$ \\
\hline $\mathrm{DBO}_{5}(\mathrm{mg} / \mathrm{l})$ & $450 \mathrm{a}$ & $30 b$ & $15 b$ & $15 b$ & $\leq 50$ \\
\hline $\mathrm{Ph}$ & $9,7 \mathrm{a}$ & $5,9 a$ & $6,9 a$ & $6,9 a$ & $6,5-8,5$ \\
\hline Cond $(\mu \mathrm{S} / \mathrm{cm})$ & $3420 \mathrm{a}$ & $17 \mathrm{~b}$ & $15 b$ & $10 \mathrm{~b}$ & $\leq 100$ \\
\hline Turb. (NTU) & $428 \mathrm{a}$ & $245 b$ & $3,9 \mathrm{c}$ & $3,5 \mathrm{c}$ & $143-538$ \\
\hline $\mathrm{PO}_{4}(\mathrm{mg} / \mathrm{l})$ & $4000 \mathrm{a}$ & $0,12 b$ & $0,1 b$ & $0,01 b$ & $\leq 10$ \\
\hline Couleur (Pt-Co) & $3701 \mathrm{a}$ & $363 b$ & $439 b$ & $137 \mathrm{~b}$ & $\leq 955$ \\
\hline $\operatorname{MOS}(\mathrm{mg} / \mathrm{l})$ & $69,45 \mathrm{a}$ & $25,75 b$ & $13,55 b$ & $12,70 \mathrm{~b}$ & $\leq 30$ \\
\hline MMS (mg/l) & $135 \mathrm{a}$ & $12,78 b$ & $18,33 b$ & $12,78 b$ & $\leq 40$ \\
\hline $\mathrm{Fe}(\mathrm{mg} / \mathrm{l})$ & $5000 \mathrm{a}$ & $0,15 b$ & $0,2 \mathrm{~b}$ & $0,0002 \mathrm{c}$ & $\leq 0,3$ \\
\hline $\mathrm{Pb}(\mathrm{mg} / \mathrm{l})$ & $20 \mathrm{a}$ & $0,09 b$ & $0,009 \mathrm{c}$ & $0,0003 d$ & $\leq 0,05$ \\
\hline $\mathrm{Cd}(\mathrm{mg} / \mathrm{l})$ & $0,08 \mathrm{a}$ & $0,09 \mathrm{a}$ & $0,0005 b$ & $0,0003 b$ & $\leq 0,001$ \\
\hline $\mathrm{NO}_{3}(\mathrm{mg} / \mathrm{l})$ & $89 a$ & $15 \mathrm{~b}$ & $0,24 \mathrm{c}$ & $0,14 \mathrm{c}$ & $\leq 20$ \\
\hline
\end{tabular}

\subsection{Pollutants Level in Different Parts of the Plant}

The $\mathrm{Fe}$ and $\mathrm{Pb}$ contents are very low in the various organs of $\mathrm{T} 2$ plants and low in the organs of B2 plants with no significant difference (Table 2). These contents are very high in the organs of plants of B2. The $\mathrm{PO}_{4}$ vary from $0.12 \mathrm{mg} / \mathrm{kg}$ in the leaves of $\mathrm{B} 3$ to $1675 \mathrm{mg} / \mathrm{kg}$ in the leaves of $\mathrm{B} 2 . \mathrm{NO}_{3}$ range from $0.03 \mathrm{mg} / \mathrm{kg}$ in $\mathrm{T} 2$ stems to $40.78 \mathrm{mg} / \mathrm{kg}$ in $\mathrm{B} 2$ roots. The Fe contents vary from $0.1 \mathrm{mg} / \mathrm{kg}$ in the roots of $\mathrm{T} 2$ to $16155.375 \mathrm{mg} / \mathrm{kg}$ in the leaves of $\mathrm{B} 2$. The $\mathrm{Pb}$ contents vary from $0.001 \mathrm{mg} / \mathrm{kg}$ in the leaves of T2 and B3 to 20 $\mathrm{mg} / \mathrm{kg}$ in the leaves of $\mathrm{B} 2$. The Cd contents in plants vary from $0.44 \mathrm{mg} / \mathrm{kg}$ in B2 to $0.397 \mathrm{mg} / \mathrm{kg}$ in B3. These contents vary from $1.32 \mathrm{mg} / \mathrm{kg}$ in the roots of B2 to $0.0006 \mathrm{mg} / \mathrm{kg}$ in the leaves and stems of T2. The $P$. purpureum plant has accumulated the various heavy metals studied, but to varying degrees. It hyperaccumulates $\mathrm{Fe}$ and $\mathrm{Pb}$, and transfers them to the leaves. But, it does not accumulate $\mathrm{Cd}$ in the leaves, rather in the roots. According to the report of the RAMSAR convention on wetlands, plants of the Poaceae family accumulate more heavy metals at the level of the leaves. The results of the work of Yagnye 2018 [22] on the plants Alternanthera sessilis and Echinochloa pyramidalis which grow in these same wet areas do not corroborate with those obtained because they hyper-accumulate heavy metals at the level of the roots. This result is in agreement with numerous observations already reported by several works like those of Almeida et al., 2011 [23]. For example, the results of Sasmaz et al., 2008 [24] show that the root parts of Typha latifolia collected near a stream exposed to metal pollution contained more metals than the aerial parts. Deny et al., 2004 [25] also observed that the $\mathrm{Pb}$ and $\mathrm{Cd}$ accumulated by Juncus effusus collected in a contaminated mud were essentially distributed at the level of the root parts compared to the aerial parts.

Table 2. Iron $(\mathrm{Fe})$, cadmium $(\mathrm{Cd})$ and lead $(\mathrm{Pb})$ contents in the different parts of plants of $T 2, B 2$ and $B 3$.

\begin{tabular}{lllll}
\hline Barrels & Tissues & Fe (mg/kg) & Pb $(\mathbf{m g} / \mathbf{k g})$ & Cd ( mg/kg) \\
\hline \multirow{4}{*}{ T2 } & Leaves & $0,2000 \pm 0,011$ & $0,0010 \pm 000$ & $0,0006 \pm 000$ \\
& Stems & $0,3000 \pm 0,017$ & $0,0015 \pm 000$ & $0,0006 \pm 000$ \\
& Roots & $0,1000 \pm 0,008$ & $0,0010 \pm 000$ & $0,00 \pm 000$ \\
& Means & $0,2000 \pm 0,012$ & $0,0011 \pm 0,000$ & $0,0004 \pm 000$ \\
& Water & $0,1000 \pm 0,010$ & $0,0900 \pm 0,008$ & $0,001 \pm 000$ \\
& Leaves & $16155,3750 \pm 432,258$ & $20,0000 \pm 1,330$ & $1,32 \pm 0,021$ \\
& Stems & $2107,5000 \pm 92,564$ & $15,0000 \pm 2,001$ & $0,001 \pm 0,000$ \\
& Roots & $425,0000 \pm 32,620$ & $12,0000 \pm 3,330$ & $00,00 \pm 0,000$ \\
& Means & $6229,2916 \pm 185,814$ & $15,6670 \pm 2,220$ & $0,44 \pm 0,007$ \\
& Water & $177,5000 \pm 12,382$ & $12,0000 \pm 1,524$ & $0,5 \pm 0,020$ \\
& Leaves & $0,3500 \pm 0,017$ & $0,0010 \pm 000$ & $1,19 \pm 0,042$ \\
& Stems & $0,4000 \pm 0,032$ & $0,006 \pm 001$ & $0,001 \pm 0,000$ \\
& Roots & $0,2400 \pm 0,090$ & $0,0070 \pm 001$ & $00,00 \pm 0,000$ \\
& Means & $0,3300 \pm 0,046$ & $0,0046 \pm 000$ & $0,397 \pm 0,014$ \\
& Water & $0,2000 \pm 0,026$ & $0,0090 \pm 0,001$ & $0,003 \pm 0,000$ \\
\hline
\end{tabular}

\subsection{Biological Parameters}

The bioaccumulation factor determined shows that $P$. purpureum contained in drums with high parameters is a lead accumulator with a value of 1.305. It is also a hyperaccumulator of $\mathrm{Fe}$ and $\mathrm{Cd}$ with values of 10.05 (B2) and 13.23 (B3) (Table 3). The leaf translocation is greater than 1 with $\mathrm{Fe}$ and $\mathrm{Pb}$ in the leaves of the bole and is equal to 0 for the $\mathrm{Cd}$ in all the bole. $P$. purpureum transfers $\mathrm{Fe}$ and $\mathrm{Pb}$ to the leaves. The coefficient of bioaccumulation of $\mathrm{Cd}$ varies from 396.66 in the leaves (B3) to 0.00 in the roots of all the barrels. For $\mathrm{Pb}$, it varies from 1.67 in the leaves of $\mathrm{B} 2$ to 0.01 in the leaves and roots of the positive control. For Fe, it varies from 91,016 in the leaves of B2 to 1 in the roots of the positive control.

The bioaccumulation factor is variable and high for $\mathrm{Pb}$ and Fe, and low for Cd. Sekabira et al., 2011 [10] explain this phenomenon by the fact that active transport is in principle specific to certain toxic cations which are potential competitors vis-à-vis essential cations. The case of $\mathrm{Cd}$ seems to be a known competitor for calcium via the membrane calcium channels. $70 \%$ of the $\mathrm{Cd}$ would enter the root in this way [9]. The translocation factor is equal to 1 for $\mathrm{Fe}$ and $\mathrm{Pb}$, and zero for $\mathrm{Cd}$; this means that the plant does not transfer the $\mathrm{Cd}$ from the roots to the leaves. These results are contrary 
to those of Yagnye 2018 [22] who demonstrated that the species $A$. sessilis and E. pyramidalis accumulate more at the level of the roots but observes a weak translocation of heavy metals towards the aerial parts. This result highlights the inability of $P$. purpureum to transfer $\mathrm{Cd}$ from these roots to its aerial parts.

However, the study by Deny et al., 2004 [25] showed a better transfer of heavy metals from the roots to the aerial parts of the dicot Oenanthe javanica compared to other monocotyledonous species. According to these authors, this phenomenon could be explained by an anatomical difference between the dicotyledonous and monocotyledonous types. Because of their broad leaves, dicots have a higher respiration rate than narrow-leaved monocots (P. purpureum), which may promote the transfer of metallic pollutants from the roots to the aerial parts.

Table 3. Bioaccumulation factors and foliar translocation of iron (Fe) and lead $(\mathrm{Pb})$.

\begin{tabular}{llllll}
\hline Barrels & & & Fe & Pb & Cd \\
\hline \multirow{3}{*}{ T2 } & BAF & & 2 & 0,0128 & 0,4 \\
& TF & & 2 & 1 & 0,6 \\
& & Leaves & 2 & 0,01 & 0,6 \\
& CBA & Stems & 3 & 0,016 & 0,6 \\
& & Roots & 1 & 0,01 & 0,00 \\
& BAF & & 10,05 & 1,305 & 8,8 \\
B2 & TF & & 38,0126 & 1,667 & 00 \\
& & Leaves & 91,016 & 1,67 & 2,64 \\
& CBA & Stems & 11,87 & 1,25 & 0,02 \\
& & Roots & 2,39 & 1 & 0,00 \\
& BAF & & 1,65 & 0,517 & 13,233 \\
& TF & & 1,45 & 0,142 & 00 \\
& & Leaves & 1,75 & 0,11 & 396,66 \\
& CBA & Stems & 2 & 0,667 & 0,33 \\
& & Roots & 1,2 & 0,778 & 00 \\
\hline
\end{tabular}

\section{Conclusion}

The present study confirms the capacity of certain aquatic plants growing in sites exposed to metal pollution to purify them. The high contents of $\mathrm{PO}_{4}(4000 \mathrm{mg} / \mathrm{l}), \mathrm{NO}_{3}(89 \mathrm{mg} / \mathrm{l})$, $\mathrm{Fe}(5000 \mathrm{mg} / \mathrm{l}), \mathrm{Pb}(20 \mathrm{mg} / \mathrm{l})$ and $\mathrm{Cd}(0.08 \mathrm{mg} / \mathrm{l})$ are greatly reduced by the filters at values well below the tolerance threshold in B3 of $0.01 \mathrm{mg} / 1,0.14 \mathrm{mg} / 1,0.0002 \mathrm{mg} / \mathrm{l}, 0.0003$ $\mathrm{mg} / \mathrm{l}$ and $0.0003 \mathrm{mg} / \mathrm{l}$ respectively. The bioaccumulation factor shows that $P$. purpureum contained in barrels where the parameters are high is lead accumulator with a value of 1.305 (B2), hyperaccumulator of iron and cadmium with values of 10.05 (B2) and 13, 23 (B3). The leaf translocation is greater than 1 with iron and lead in the leaves of the boles. $P$. purpureum transfers $\mathrm{Fe}$ and $\mathrm{Pb}$ to the leaves. The increase in metal concentrations in the root parts of this plant shows that the aquatic plants collected in this polluted site (mangroves of the monkey woods) perfectly reflect the pollution levels to which the environments in which they develop are exposed. The treatment of sites polluted by metals by using aquatic plants represents a passive approach, of low cost would restore long term urban wetlands in order to keep them in balance for a sustainable development.

\section{References}

[1] Morel., J. 2007. Water resources on earth origin, use and prospects in the context of Climate Change. Economics of production and international integration, Cameroon.

[2] Kone, D. 2002. Purification of wastewater by microphyte and macrophyte lagooning in West and Central Africa: inventory, purification performance and sizing criteria. DEA in environmental sciences.

[3] Comeau, Y., Brisson, J., and Chazarenc, F. 2006. Treatment of fish sludge by artificial marsh and dephosphatizing filter bed. Continental Aquaculture Research and Development Corporation, INC.

[4] Rejsek, F. 2002. Water analysis regulatory and technical aspects. CRDP, Aquitaine. Paris.

[5] Grosclaude, G., 1999. Water, volume 1: Natural environment and volume 2: Uses and pollutants. Versailles, National Institute of Agronomic Research.

[6] Fonkou, T., Fonteh, M., F., Djousse, K., M., and Amougou, A., 2010. Performances of vegetated beds with Echinochloa pyramidalis in the purification of wastewater from distillery in subsaharan Africa. Tropicultura, 28 (2): 69-76.

[7] Onguene, R. 2014. Multiscale modeling of ocean circulation in Central Africa, and the abyssal plain at the Cameroon estuary. Doctorate/Ph. D in Physics, UT3 Paul Sabatier, Cotutelle international with the Faculty of Sciences of the University of Yaoundé I.

[8] Ba'ana, E., L., Ndjouondo, G., P., Nwamo, R., D., Fankem, H., and Dibong, S., D. 2017. Evaluation of the contents of some chemical parameters on the nutritional quality of Ipomoea batatas (sweet potato) and Zea mays (corn) grown in the wetlands of Kambo and Longmayagui rivers (Douala). International Journal of Innovation and Scientific Research, 33 (1), 56-69.

[9] Ma, L., Q., Komar, K., M., Tu, C., Zhang, W., Cai, Y., and Kenelly, E., D. 2001. A Fern that hyper-accumulates arsenic. Nature, 409, 579-582.

[10] Sekabira, K., H., Oryem-Origa, H., Mutumba, G., Kakudidi, E., and Basamba, T., A. 2011. Heavy metal phytoremediation by Commelina benghalensis (L) and Cynodon dactylon (L) growing in Urban stream sediments. International Journal of Plant Physiology and Biochemistry, 3 (8), 133-142.

[11] Jora. 1993. Algerian environmental standards for discharges of industrial liquid effluents, Ministry of the Environment.

[12] Bachi, O., E. 2010. Diagnosis on the valuation of some plants from the sewage treatment plant of the old Kasar de Temacine station. Master thesis in Saharan Agronomy. Kasdi Merbah Ouargla University.

[13] Smith, R. (1987) Analysis and interpretation of waterquality trends in major U.S. rivers, 1974-81. USGS paper Washington.

[14] Slimani, R. 2006. Contribution to the evaluation of environmental pollution indicators in the Ouargla region: case of waste water (agricultural and urban). Master thesis, Ouargla University. 

«Bois des Singes» by Planted Filters of Pennisetum purpureum (Douala, Cameroon)

[15] Eva, R., Catherine, B., Philippe, R., and Alain, H., C. 2011. Wastewater treatment by filters planted with vertical flow reeds (FPRv). Environmental Technologies and Pollution Action ACV Model Action.

[16] Iwema, A., Raby, D., Lesavre, J., Boutin, C., Dodane, P., Liènard, A., Molle, P., Beck, C., Sadowski, G., Merlin, Dap, S., Ohresser, C., Poulet, J., Reeb, G., Werckmann, M., and Esser, D. 2005. Purification of wastewater by filters planted with macrophyte: technical recommendations for design and construction. Water agency: RM \& C.

[17] Ramsar, 2013. The Ramsar Convention Manual. Ramsar, Iran.

[18] Dekhil, S. W., and Zaibet, M. 2013. Treatment of urban wastewater by activated sludge in the town of Bordj Bou Arreridj carried out by the ONA wastewater treatment plant. Master thesis, Mohamed EL Bachir Elibrahimi-Bordj Bou Arreridj University, Faculty of Science and Technology, Department of Environmental Engineering.

[19] Dosnon-Olette, R. 2009. Phytoremediation of water contaminated by pesticides: tolerance and elimination capacity by aquatic plants. Doctoral thesis, University of Reims Champagne-Ardenne.

[20] Assadian, N., W., Esparza, L., C, Fenn, L., B., Ali, A., S., Miyamoto, S., Figueroa, U., V., and Warrick, A., W. 1998.
Spatial variability of heavy metals in irrigated alfalfa fields in the upper Rio Grande River Basin, Agric. Water Manage, 36, 141-156.

[21] Vila, M. 2006. Use of agronomic and lacustrine plants in the depollution of soils contaminated by RDX and TNT: laboratory approaches. Doctoral Thesis, Doctoral School: Transfer, Fluid Dynamics, Energetics and Processes, Department of Agroresources Science.

[22] Yagnye, E. 2018. Phytorestoration of water polluted with heavy metals from domestic and industrial waste in the city of Douala. Master II dissertation in Biology and Physiology of Plant Organisms, University of Douala.

[23] Almeida, C., M., Mucha, A., P., and Teresa, V., M. 2011. Role of different salt marsh plants on metal retention in an urban estuary (Lima estuary, NW Portugal). Estuar Coast Shelf Sci., $91(2), 243-249$.

[24] Sasmaz, A., Obek, E., and Hasar, H. 2008. The accumulation of heavy metals in Typha latifolia L. grown in a stream carrying secondary effluent. Ecol Eng., 33 (3-4), 278-284.

[25] Deng, H., Ye, Z., H., and Wong, M., H. 2004. Accumulation of lead, zinc, copper and cadmium by 12 wetland plant species thriving in metal-contaminated sites in China. Environmental Pollution, 132 (1), 29-40. 